\title{
An Immunofluorescence Assay to Detect Urediniospores of Phakopsora pachyrhizi
}

\author{
Fulya Baysal-Gurel, Melanie L. Lewis Ivey, and Anne Dorrance, Department of Plant Pathology, The Ohio State \\ University, Ohio Agricultural Research and Development Center, Wooster; Douglas Luster and Reid Frederick, \\ USDA ARS Foreign Diseases and Weed Science Research Unit, Ft. Detrick, MD; Jill Czarnecki, Naval Medical \\ Research Center, Biological Defense Research Directorate, Silver Spring, MD; Michael Boehm, Department of \\ Plant Pathology, The Ohio State University, Columbus; and Sally A. Miller, Department of Plant Pathology, The \\ Ohio State University, Ohio Agricultural Research and Development Center, Wooster
}

\begin{abstract}
Baysal-Gurel, F., Ivey, M. L. L., Dorrance, A., Luster, D., Frederick, R., Czarnecki, J., Boehm, M., and Miller, S. A. 2008. An immunofluorescence assay to detect urediniospores of Phakopsora pachyrhizi. Plant Dis. 92:1387-1393.

An indirect immunofluorescence spore assay (IFSA) was developed to detect urediniospores of Phakopsora pachyrhizi, utilizing rabbit polyclonal antisera produced in response to intact nongerminated (SBR1A) or germinated (SBR2) urediniospores of $P$. pachyrhizi. Both antisera were specific to Phakopsora spp. and did not react with other common soybean pathogens or healthy soybean leaf tissue in enzyme-linked immunosorbent assay (ELISA). SBR1A and SBR2 bound to $P$. pachyrhizi and P. meibomiae urediniospores were detected with goat anti-rabbit Alexa Fluor 488-tagged antiserum using a Leica DM IRB epifluorescent microscope with an I3 blue filter (excitation 450 to $490 \mathrm{~nm}$, emission $515 \mathrm{~nm}$ ). The assay was performed on standard glass microscope slides; double-sided tape was superior to a thin coating of petroleum jelly both in retaining spores and in immunofluorescence. The IFSA was used to confirm the identity of $P$. pachyrhizi urediniospores captured on glass slides from passive air samplers from Georgia, Kentucky, and Ohio during 2006.
\end{abstract}

Additional keywords: field trap, soybean rust

Soybean rust has been reported in Asia, Africa, South and Central America, the United States, and most recently Canada (28,38; A. Tenuta, personal communication). Significant yield losses on soybean crops have occurred in Asia, Africa, Australia, and nearly all tropical countries in both the eastern and western hemispheres where soybeans are grown (1-3,21,28, $31,33,34,42)$. Soybean rust is caused by two Phakopsora species, P. pachyrhizi Sydow and P. meibomiae (Arthur) Arthur, of which $P$. pachyrhizi is the more aggressive (28). P. meibomiae is not considered a serious threat to soybean production. In Brazil, P. pachyrhizi was estimated to cost growers approximately $\$ 1.2$ billion in 2003 , with $\$ 500$ million in direct yield losses to the disease and $\$ 700$ million resulting from use of fungicides (42). It is predicted that $P$. pachyrhizi may negatively impact soybean production in the United

Corresponding author: Sally A. Miller

E-mail: miller.769@osu.edu

Accepted for publication 6 June 2008 .

doi:10.1094/PDIS-92-10-1387

(C) 2008 The American Phytopathological Society
States with annual losses between $\$ 240$ million and $\$ 2.0$ billion, depending on the severity of the disease $(23,28)$.

$P$. pachyrhizi can be managed with welltimed fungicide applications $(29,30)$. In the United States, numerous products containing triazole and strobilurin type fungicides have been labeled. Both types of products have good activity when applied close to the time when spores arrive in the field $(12,18)$.

Currently, an emphasis is being placed on tracking the movement of soybean rust through soybean production regions in the United States, and developing predictive models for future fungicide application and timing decisions (41). The IPM PIPE system $(16,39)$, established to monitor and predict diseases such as soybean rust, is dependent upon accurate and timely detection and identification of pathogen propagules to ensure the efficacy of both decision tools and disease management. Methods are needed to efficiently detect and correctly identify and distinguish $P$. pachyrhizi urediniospores from other plant-pathogenic fungal spores for timely and appropriate applications of fungicides.

Techniques for trapping and direct assessment of $P$. pachyrhizi urediniospores would be beneficial to all soybean produc- ers worldwide. Identification of trapped spores of $P$. pachyrhizi currently requires experienced mycologists, specialized equipment, and many hours examining the trapped spores microscopically. Visualization and enumeration of airborne spores through bright field microscopic examination of spores collected in spore traps have been utilized for a number of plant pathogens (15). However, such methods require considerable amounts of time and expertise in spore morphology if accurate counts are to be obtained. The use of this technique is further limited when fungal spores that are morphologically similar are captured together. Technological advances in fungal diagnostics, using either antibody- or nucleic acid-based assays, allow for the accurate differentiation of fungal species $(5,14,40)$.

Air sampling formats can be combined with serological assays to detect and identify airborne fungal spores $(17,20)$. For example, Kennedy et al. (19) developed a direct fungal spore monitoring process in which airborne spores of Mycosphaerella brassicicola and Botrytis cinerea were trapped in a 96-well enzyme-linked immunosorbent assay (ELISA) plate using a specialized particle sampler and detected by rabbit polyclonal antibodies.

In this study, we report the production of specific polyclonal antibodies for $P$. pachyrhizi and describe the development of an immunofluorescence spore assay (IFSA) for the detection of $P$. pachyrhizi urediniospores in spore trapping systems. This type of assay will greatly assist in the monitoring of $P$. pachyrhizi urediniospores for both fungicide recommendations and confirmation of modeling efforts. Preliminary results of this research have been reported previously (4).

\section{MATERIALS AND METHODS}

Microbial cultures. $P$. pachyrhizi and $P$. meibomiae isolates were maintained and propagated at the USDA-ARS Foreign Disease-Weed Science Research Unit (FDWSRU) Biosafety Level 3 (BSL-3) Plant Pathogen Containment Facility at Fort Detrick, MD (26) under an appropriate USDA Animal Plant Health Inspection 
Service permit. Urediniospores were harvested using a mechanical harvester (9) and both germinated and nongerminated urediniospores were killed in ethylene oxide prior to use in antiserum and assay development according to the conditions of APHIS permit for removing material from the BSL-3 containment facility. All other fungal and bacterial cultures were collected and maintained at The Ohio State University.

Polyclonal antibody production. Four different fractions of $P$. pachyrhizi urediniospores were used to generate five antisera (Table 1). These fractions represented distinct approaches to produce polyclonal antisera against surface and internal antigens of $P$. pachyrhizi. Antisera were generated against surface antigens of intact nongerminated and germinated $P$. pachyrhizi isolate Taiwan 72-1 (TW 72-1) urediniospores, pulverized germinated spores, and spore wall fractions. To generate antibodies against surface antigens of intact, nongerminated spores, urediniospores that were stored frozen in liquid nitrogen were suspended in phosphatebuffered saline $\left(4.3 \mathrm{mM} \mathrm{NaHPO}_{4}, 1.4 \mathrm{mM}\right.$ $\mathrm{KH}_{2} \mathrm{PO}_{4}, 137 \mathrm{mM} \mathrm{NaCl}, 2.7 \mathrm{mM} \mathrm{KCl}, \mathrm{pH}$ 7.3) (PBS) at two different concentrations and killed by treatment with ethylene oxide. To generate antibodies against surface and internal antigens of germinated spores, $1.0 \mathrm{~g} \mathrm{FW}$ of urediniospores was floated on the surface of 3 liters of sterile distilled $\mathrm{H}_{2} \mathrm{O}$ containing $50 \mu \mathrm{g} / \mathrm{ml}$ ampicillin and 50 $\mu \mathrm{g} / \mathrm{ml}$ streptomycin in glass pans and allowed to germinate at room temperature overnight. The germinated urediniospore mat was washed in 3 liters of $0.01 \%$ Tween $20 \mathrm{vol} / \mathrm{vol}$ on a rotary shaker at 100 rpm for $2 \mathrm{~h}$ at RT. The germinated spores were collected on Whatman no. 1 filter paper, sterilized overnight with ethylene oxide, and split into two fractions. Onethird of the germinated spore fraction was directly suspended in PBS and used for injection. The remaining two-thirds of the germinated spores were resuspended in PBS, flash frozen in liquid nitrogen, and pulverized in a bead beater (Cole Parmer, Vernon Hills, IL) using three 25-s bursts at 2,500 $\mathrm{rpm}$. This pulverized fraction was then split into two fractions. One-half of the pulverized germinated spores were used directly for injection. The other half of the pulverized, germinated spores were resuspended in PBS containing $500 \mathrm{mM}$ $\mathrm{NaCl}$ (PBSS), vortexed, centrifuged at 325 $\times g$, and the pellet washed with PBSS. This process was repeated three times to re- move soluble materials and leave a washed cell wall fraction. The final washed cell wall pellet was resuspended in PBS for injection. The protein content of each fraction was measured using the method of Markwell et al. (24), and protein concentrations were adjusted to optimize the immune response (Table 1). All antiserum production was performed using New Zealand white rabbits by a commercial vendor (Bushover Biologicals, Vassalboro, ME) under contract to the U.S. Navy Biological Defense Research Directorate (BDRD) in Silver Spring, MD conforming to approved animal handling and BDRD Animal Care and Use Committee policies and protocols. Immunization schedules were performed according to the vendor's protocols. Bleeds were conducted until optimal titers were obtained, based upon standardized ELISA screening protocols with target immunogens.

Polyclonal antiserum specificity-indirect ELISA. The five polyclonal antisera (SBR1A, SBR1B, SBR2, SBR3, and SBR4) developed in response to four different $P$. pachyrhizi immunogens were evaluated for specificity using an indirect ELISA protocol with ethylene oxide-killed urediniospores of P. pachyrhizi and P. meibomiae, and pure culture extracts of four bacterial pathogens (Pseudomonas syringae pv. syringae van Hall, $P$. syringae pv. phaseolicola, Xanthomonas campestris pv. glycines (Nakano) Dye, Clavibacter michiganensis subsp. insidiosus) and six fungal pathogens (Botrytis cinerea Pers.:Fr., Colletotrichum acutatum Simmonds, C. gloeosporioides (Penz.) Penz. \& Sacc., Ustilago tritici (Pers.) Rostr., Puccinia graminis f. sp. tritici Eriks., Rhizoctonia solani Kuhn). Soybean leaf extracts prepared from leaves with bacterial pustules caused by $X$. campestris pv. glycines, frogeye leaf spot caused by Cercospora sojina K. Harav, bacterial blight caused by $P$. syringae pv. glycinea (Coerper) Young, Dye \& Wilkie, Septoria leaf spot caused by Septoria glycines Hemmi, and powdery mildew caused by Microsphaera diffusa Cooke \& Peck, and healthy leaves from 183 soybean cultivars were evaluated. In addition, extracts of wheat tissue infected with $U$. tritici (Pers.) Rostr. and P. graminis f. sp. tritici Eriks were tested.

Germinated and nongerminated urediniospores of P. pachyrhizi and P. meibomiae were suspended in PBS to a final concentration of $10 \mu \mathrm{g}$ protein $/ \mathrm{ml}$. Pure cultures of each fungal pathogen (except isolates of Colletotrichum) were grown in potato

Table 1. Polyclonal antisera developed in response to antigens of Phakopsora pachyrhizi

\begin{tabular}{llll}
\hline Antiserum & Immunogen preparation & Immunogen amount & Boost amount \\
\hline SBR1A & Nongerminated urediniospores & $5 \mathrm{mg}$ spores FW & $2.0 \mathrm{mg}$ spores FW \\
SBR1B & Nongerminated urediniospores & $2.5 \mathrm{mg}$ spores FW & $2.0 \mathrm{mg}$ spores FW \\
SBR2 & Germinated urediniospores & $0.25 \mathrm{mg}$ protein & $0.10 \mathrm{mg}$ protein \\
SBR3 & Pulverized, germinated urediniospores & $0.325 \mathrm{mg}$ protein & $0.10 \mathrm{mg}$ protein \\
SBR4 & Wall fraction germinated urediniospores & $0.05 \mathrm{mg}$ protein & $0.125 \mathrm{mg}$ protein \\
\hline
\end{tabular}

dextrose broth (PDB) at room temperature without shaking for 3 to 6 days, depending on the organism. Colletotrichum isolates were grown in glucose casein medium as previously described (22). Mycelium from each pathogen was harvested by filtering through sterile Whatman no. 2 filter paper. Cultures were air-dried overnight, ground in liquid nitrogen, and resuspended in PBS to a final concentration of $10 \mu \mathrm{g}$ protein $/ \mathrm{ml}$. Protein concentrations were determined using the Bradford assay (7). Pure cultures of each bacterial pathogen were grown in nutrient broth yeast extract medium without glucose and incubated at $28^{\circ} \mathrm{C}$ for $36 \mathrm{~h}$ with shaking ( 250 rpm). Bacteria were harvested by centrifugation $(8,100 \times g, 10 \mathrm{~min})$, and the pellets were resuspended in PBS to final concentrations of $10^{6}$ and $10^{2} \mathrm{CFU} / \mathrm{ml}$. Soybean leaf and wheat tissue extracts were prepared by grinding $0.5 \mathrm{~g}$ of diseased soybean or wheat tissue in Agdia mesh sample bags containing $3 \mathrm{ml}$ of BEB1 buffer (Agdia, Inc., Elkhart, IN). Extracts were collected, transferred into $1.5-\mathrm{ml}$ sterile microfuge tubes $(250-\mu \mathrm{l}$ aliquots) and stored at $-20^{\circ} \mathrm{C}$.

Indirect ELISAs were set up by adding $200 \mu \mathrm{l}$ of each sample to each of two wells of an Immulon 2HB, 96-well flat bottom microtiter plate. Each assay contained healthy tissue extract and BEB1 buffer as negative controls. Microtiter plates were placed into a sealed moist chamber and incubated overnight at $4^{\circ} \mathrm{C}$. The microtiter plates were washed six times with PBS containing $0.01 \%$ vol/vol Tween 20 (PBSTween) and blocked with blocking buffer (PBS containing 5\% skim milk) for $1 \mathrm{~h}$ at $37^{\circ} \mathrm{C}$. Plates were washed again with PBSTween six times, $100 \mu \mathrm{l}$ of diluted primary antibody (1:10 in dilution buffer [PBSTween with $5 \%$ skim milk]) was added to each well, and the plates were incubated at $37^{\circ} \mathrm{C}$ for $1 \mathrm{~h}$ within a sealed moist chamber. Plates were washed six times with PBS-Tween, $100 \mu \mathrm{l}$ of diluted alkaline phosphatase conjugate $(1: 3,000$ in dilution buffer) was added to each well, and the plates were incubated at $37^{\circ} \mathrm{C}$ for $1 \mathrm{~h}$ within a sealed moist chamber. Plates were again washed six times with PBS-Tween, and $100 \mu \mathrm{l}$ of PNP substrate buffer ( 1 tablet PNP/5 ml of $1 \times$ PNP substrate buffer; Agdia) was added to each well. Plates were incubated at $37^{\circ} \mathrm{C}$ for $15 \mathrm{~min}$ and visualized at $405 \mathrm{~nm}$ (2-min intervals for $10 \mathrm{~min}$ ) using an automated microplate reader. A positive sample was scored when the absorbance $(405 \mathrm{~nm})$ was at least two times the absorbance of the healthy tissue (negative control).

IFSA optimization. Several parameters were evaluated to optimize the immunofluorescence staining procedure including: (i) reaction of different primary antisera, (ii) antiserum working dilution with different buffers (PBS and PBS-Tween, Agdia, Inc.), (iii) working dilutions with the 
secondary antiserum (Alexa Fluor 488 goat anti-rabbit IgG $(\mathrm{H}+\mathrm{L})$, Invitrogen Molecular Probes, Eugene, OR), (iv) primary and secondary antiserum incubation time and temperature, (v) use of a blocking buffer (PBS containing $2 \%$ bovine serum albumin [BSA], Sigma Chemical Co., St. Louis, MO) and 5\% goat serum (Sigma)], and (vi) type of washing buffer. Spores were observed using an epifluorescence microscope and rated visually using a scale of 1 to 4 where $1=$ no fluorescence, 2 = weak fluorescence, 3 $=$ good fluorescence (clearly positive), and 4 = bright fluorescence (Fig. 1).

Assay optimization was conducted using standard glass microscope slides coated with a thin layer of petroleum jelly or affixed with a 51-mm strip of 13- or 19-mmwide double-sided tape (Scotch Permanent Double-Sided Tape, 3M Corporation, St. Paul, MN). Dry urediniospores were drawn $\sim 1 \mathrm{~mm}$ into the tip of a $10-\mu \mathrm{l}$ glass PCR micropipette and expelled onto the double-sided tape or petroleum jelly. For a urediniospore capture treatment, double-sided tape was pressed onto the petroleum jelly-coated slides to remove the urediniospores and affixed to a glass slide. A $500-\mu 1$ aliquot of primary antiserum was added to the urediniospores and incubated in a covered petri dish. The glass microscope slide containing primary antiserum-labeled urediniospores was then washed six times (30 to $60 \mathrm{~s}$ incubation each time) in washing buffer. A 500- $\mu$ l aliquot of Alexa Fluor 488-labeled goat anti-rabbit IgG was applied over the surface of the slide and incubated in the dark. The slide was washed six times as described above. One drop (approx. 100 $\mu \mathrm{l})$ of PBS-Tween was placed over the surface of the slide, which was then was covered with a coverslip. The edges of the coverslip were sealed to the microscope slide with clear nail polish. Samples were stored in the dark at $22^{\circ} \mathrm{C}$ for up to 2 months.

Polyclonal antiserum specificityIFSA. Polyclonal antiserum SBR1A was tested for specificity using the IFSA protocol on standard glass microscope slides either coated with petroleum jelly or affixed with double-sided tape. Spores of five fungal pathogens from infected tissue (Puccinia graminis f. sp. tritici, Phragmidium sp., Ustilago tritici, Alternaria sp., and Botrytis cinerea) and ethylene oxide-

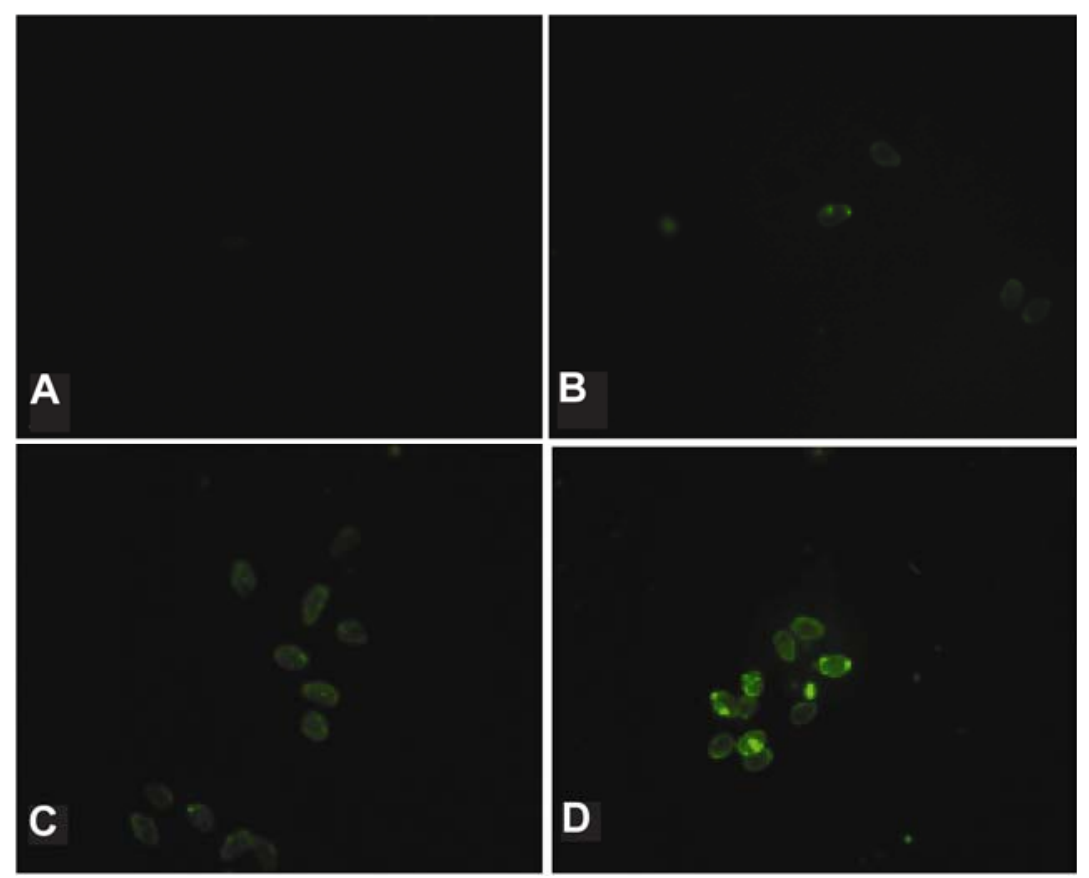

Fig. 1. The visual fluorescence intensity score of urediniospores of Phakopsora pachyrhizi determined using an immunofluorescence spore assay (IFSA) ( $20 \times$ objective). A, $1=$ no fluorescence; $\mathbf{B}, 2=$ weak fluorescence; $\mathbf{C}, 3$ = good fluorescence (clearly positive); and $\mathbf{D}, 4=$ bright fluorescence.
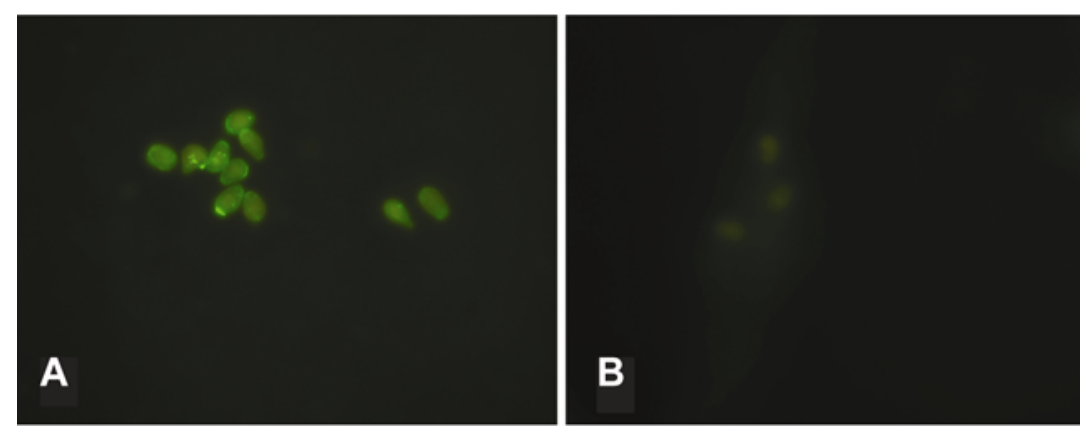

Fig. 2. Visualization of urediniospores of Phakopsora pachyrhizi on glass microscope slides in an immunofluorescence spore assay (IFSA) with polyclonal antiserum SBR1A using A, double-sided tape, and B, petroleum jelly ( $20 \times$ objective).

Table 2. Specificity of polyclonal antisera developed in response to Phakopsora pachyrhizi antigens to fungal and bacterial plant pathogen and healthy soybean cultivar extracts in an enzyme-linked immunosorbent assay (ELISA)

\begin{tabular}{|c|c|c|c|c|c|}
\hline \multirow[b]{2}{*}{ Extract } & \multicolumn{5}{|c|}{ Reactivity in ELISA ${ }^{a}$} \\
\hline & SBR1A & SBR1B & SBR2 & SBR3 & SBR4 \\
\hline Phakopsora pachyrhizi isolate TW 72-1 & + & + & + & + & + \\
\hline Phakopsora meibomiae isolate PR 76 & + & + & - & - & - \\
\hline $\begin{array}{l}\text { Pseudomonas syringae pv. syringae and pv. phaseolicola, Xanthomonas campestris } \\
\text { pv. glycines, Clavibacter michiganensis subsp. insidiosus, Botrytis cinerea, } \\
\text { Colletotrichum acutatum, C. gloeosporioides, Ustilago tritici }\end{array}$ & - & - & - & - & - \\
\hline Rhizoctonia solani & - & - & - & + & + \\
\hline Puccinia graminis f. sp. tritici & - & - & - & - & + \\
\hline $\begin{array}{l}\text { Diseased soybean tissue: } P \text {. syringae } \mathrm{pv} \text {. glycinea, } X \text {. campestris pv. glycines, } \\
\text { Cercospora sojina, Septoria glycines, Microsphaera diffusa }\end{array}$ & - & - & - & - & - \\
\hline Symptomless soybean tissue: 183 cultivars & - & - & - & - & - \\
\hline
\end{tabular}

${ }^{\text {a }}$ Samples for which the absorbance at $405 \mathrm{~nm}$ is greater than or equal to $2 \times$ that of the negative control (healthy soybean tissue extract) are considered positive (+). Samples are considered negative (-) when the $A_{405}$ is less than $2 \times$ the absorbance of the negative control. 
Table 3. Fluorescence intensity of Phakopsora pachyrhizi urediniospores in an immunofluorescence spore assay (IFSA) utilizing various assay parameters

\begin{tabular}{|c|c|c|c|c|c|}
\hline \multirow[b]{2}{*}{ Parameter } & \multirow[b]{2}{*}{ Variable } & \multicolumn{4}{|c|}{ Fluorescence intensity ${ }^{a}$} \\
\hline & & 1 & 2 & 3 & 4 \\
\hline \multirow[t]{2}{*}{ Primary antiserum } & SBR1A & & & & + \\
\hline & SBR2 & & & + & \\
\hline \multirow{2}{*}{ Dilution buffer type } & PBS & & + & & \\
\hline & PBS-Tween & & & & + \\
\hline \multirow[t]{3}{*}{ Primary antiserum dilution } & $1: 100$ & & & & $t^{\mathrm{b}}$ \\
\hline & $1: 250$ & & & & $+^{\mathrm{b}}$ \\
\hline & $1: 500$ & & & & + \\
\hline \multirow[t]{3}{*}{ Secondary antiserum dilution } & $1: 100$ & & & & $t^{\mathrm{b}}$ \\
\hline & $1: 250$ & & & & $+^{\mathrm{b}}$ \\
\hline & $1: 500$ & & & & + \\
\hline \multirow[t]{3}{*}{ Primary antiserum incubation time } & $1 \mathrm{~h}$ & & & + & \\
\hline & $2 \mathrm{~h}$ & & & & + \\
\hline & $3 \mathrm{~h}$ & & & & + \\
\hline \multirow[t]{3}{*}{ Secondary antiserum incubation time } & $1 \mathrm{~h}$ & & & & + \\
\hline & $2 \mathrm{~h}$ & & & & + \\
\hline & $3 \mathrm{~h}$ & & & & $t^{\mathrm{b}}$ \\
\hline \multirow[t]{2}{*}{ Primary antiserum incubation temperature } & $22^{\circ} \mathrm{C}$ & & & & + \\
\hline & $37^{\circ} \mathrm{C}$ & & + & & \\
\hline \multirow[t]{2}{*}{ Secondary antiserum incubation temperature } & $22^{\circ} \mathrm{C}$ & & & & + \\
\hline & $37^{\circ} \mathrm{C}$ & & + & & \\
\hline \multirow[t]{2}{*}{ Blocking step: $\mathrm{PBS}+2 \% \mathrm{BSA}+5 \%$ goat serum } & Yes & & & & + \\
\hline & No & & & & + \\
\hline \multirow[t]{3}{*}{ Washing buffer } & PBS & & + & & \\
\hline & PBS-Tween & & & & + \\
\hline & Distilled water & + & & & \\
\hline
\end{tabular}

a Fluorescence of urediniospores was rated visually using a scale of 1 to 4 where $1=$ no fluorescence, $2=$ weak fluorescence, $3=$ good fluorescence (clearly positive), and $4=$ bright fluorescence.

${ }^{\mathrm{b}}$ Indicates that the background was cloudy.

Table 4. Reactivity of polyclonal antiserum SBR1A with killed urediniospores of Phakopsora pachyrhizi isolates in an immunofluorescence spore assay (IFSA) with polyclonal antiserum SBR1A

\begin{tabular}{|c|c|c|c|c|}
\hline Origin & Year & Isolate & Source & $\begin{array}{l}\text { Reactivity } \\
\text { in IFSA }\end{array}$ \\
\hline \multirow[t]{3}{*}{ Louisiana } & 2004 & LA04-1 & R. Schneider ${ }^{\mathrm{b}}$, Ben Hur & 4 \\
\hline & 2004 & LA04-2 & R. Schneider, Ben Hur & 4 \\
\hline & 2004 & LA04-3 & R. Schneider, St. Gabrielle & 4 \\
\hline \multirow[t]{3}{*}{ Alabama } & 2004 & AL04-1 & R. Frederick ${ }^{\mathrm{c}}$, Mobile County & 4 \\
\hline & 2004 & AL04-2 & R. Frederick, Baldwin County & 4 \\
\hline & 2004 & AL04-3 & R. Frederick, Baldwin County & 4 \\
\hline \multirow[t]{2}{*}{ Hawaii } & 1994 & HW94-1 & E. Kilgore ${ }^{\mathrm{d}}$, Oahu & 4 \\
\hline & 1998 & HW98-1 & E. Kilgore, Oahu & 4 \\
\hline Australia & 1979 & AU79-1 & Unknown & 4 \\
\hline Brazil & 2001 & BZ01-1 & J. T. Yorinorie, Parana & 4 \\
\hline China & 2003 & CH03-1 & Z. $\mathrm{Ma}^{\mathrm{f}}$, YunNan Province & 4 \\
\hline Colombia & 2004 & $\mathrm{CO} 04-1$ & R. Tisnes, Valle del Cauca, Caicedonia & 4 \\
\hline India & 1973 & IN 73-1 & D. N. Thapliyal, Pantnagar & 4 \\
\hline Paraguay & 2001 & PG01-2 & W. M. Morel ${ }^{\mathrm{g}}$, Capitan Miranda & 4 \\
\hline Philippines & 1977 & PH 77-1 & Bureau of Plant Industries, Los Banos & 4 \\
\hline South Africa & 2001 & SA 01-1 & Z. A. Pretorius ${ }^{\mathrm{h}}$, Natal Province & 4 \\
\hline \multirow{2}{*}{ Thailand } & 2001 & TH01-1 & S. Poonpolguli, Chaingmai & 4 \\
\hline & 2002 & TH02-1 & S. Poonpolgul, Chaingmai & 4 \\
\hline \multirow[t]{2}{*}{ Taiwan } & 1972 & TW 72-1 & Lung-Chi Wu, Taipei & 4 \\
\hline & 1980 & TW 80-2 & AVRDCj, Taiwan & 4 \\
\hline Vietnam & 2005 & VT05-1 & N. Binh ${ }^{\mathrm{k}}$, Hanoi & 4 \\
\hline Zimbabwe & 2001 & ZM 01-1 & C. Levy', Harare & 4 \\
\hline
\end{tabular}

a Fluorescence of urediniospores was rated visually using a scale of 1 to 4 where $1=$ no fluorescence, 2 = weak fluorescence, $3=$ good fluorescence (clearly positive), and $4=$ bright fluorescence.

b Department of Plant Pathology and Crop Physiology, Louisiana State University, Baton Rouge, LA.

${ }^{\mathrm{c}}$ Collections made with the assistance of T. Johnson, R. Wingard, and W. Harrison, Alabama Department of Agriculture and Industries, and E. Sikora, Alabama Cooperative Extension System, Auburn University.

${ }^{\mathrm{d}}$ Hawaii Department of Agriculture, Hilo, HI.

e Embrapa soja, Londrina, Brazil.

${ }^{f}$ China Agricultural University, Beijing, China.

g Centro Regional Investigacion de Agricola, Capitan Miranda, Paraguay.

${ }^{h}$ University of the Free State, Bloemfontein, South Africa.

i Thailand Department of Agriculture, Bangkok, Thailand.

j Asian Vegetable Research and Development Center, Taipei, Taiwan.

${ }^{\mathrm{k}}$ Plant Protection Research Institute, Hanoi, Vietnam.

${ }^{1}$ Commercial Farmers Union of Zimbabwe, Harare, Zimbabwe.
Immunofluorescence microscopy. Images were captured using a Leica DMIRB (Leica Microsystems, Wetzlar, Germany) epifluorescence microscope equipped with an Optronics Magnafire camera (Optronics Engineering, Goleta, CA, or http://optron ics.com), digitized with a Magnafire image capture board, and processed with Adobe Photoshop CS (Adobe, Seattle, WA). A USH-102DH-100W ultra-high-pressure mercury lamp (USHIO America, Inc., Cypress, CA) was used as the exciting light source. Images were viewed in the blue excitation range (filter set $\mathrm{I}_{3}$ - excitation filter BP450-490 nm and emission filter BP515 $\mathrm{nm}$ ) with a $20 \times$ objective (N.A. 0.12 ); the exposure time for image capture was always $1.037 \mathrm{~s}$.

Immunomonitoring of field-trapped spores. Double-sided tape was affixed to standard glass microscope slides, or slides were thinly coated with petroleum jelly, and placed in passive spore traps in Georgia, Kentucky, and Ohio soybean fields during 2006. Each trap was designed to rotate with the wind and was approximately $1.8 \mathrm{~m}$ above the soybean canopy. Slides were collected at 7-day intervals and heated in an oven for $48 \mathrm{~h}$ at $56^{\circ} \mathrm{C}$ to kill spores prior to shipment. The IFSA was conducted on each slide and spores were viewed as described above. Nonspecific binding of the secondary antiserum to the petroleum jelly resulted in nonspecific background fluorescence and weak fluorescence of $P$. pachyrhizi urediniospores. Therefore, spores were lifted from petroleum jelly using double-sided tape, which was then fixed onto a new glass microscope slide for IFSA.

\section{RESULTS}

Polyclonal antiserum specificity-indirect ELISA. Antisera SBR1A and SBR1B, produced against nongerminated urediniospores, reacted positively with both $P$. pachyrhizi and $P$. meibomiae urediniospores in ELISA, while antiserum SBR2, produced against intact germinated urediniospores, reacted only with $P$. pachyrhizi urediniospores. Antisera SBR3 and SBR4, produced against a crude extract of pulverized germinated urediniospores and cell walls of pulverized germinated urediniospores, respectively, reacted with urediniospores of both Phakopsora species, but also cross-reacted with $R$. solani and $P$. graminis f. sp. tritici. None of the antisera reacted with $B$. cinerea, $C$. acutatum, $C$. gloeosporioides, U. tritici, the four bacterial pathogens, or leaf extracts of any of the 183 healthy soybean cultivars tested (Table 2).

Immunofluorescence spore assay optimization. Both primary antisera (SBR1A and SBR2) reacted with urediniospores of $P$. pachyrhizi; however, urediniospores treated with SBR1A were brighter, with an immunofluorescence score of 4 , than those treated with SBR2, with an immuno- 
fluorescence score of 3 (Table 3). PBSTween was more effective than PBS as a dilution buffer and wash buffer, resulting in more intense fluorescence of urediniospores (intensity score of 4) than for PBS (intensity score of 2). All of the dilutions of the primary and secondary antiserum resulted in bright fluorescence with urediniospores of $P$. pachyrhizi. Increasing the time of the primary antiserum incubation from 1 to $2 \mathrm{~h}$ increased the fluorescence of urediniospores of $P$. pachyrhizi, but increasing the incubation time from 2 to $3 \mathrm{~h}$ did not increase the fluorescence intensity. Fluorescence intensity of $P$. pachyrhizi urediniospores did not differ with secondary antibody incubation time. An incubation temperature of $37^{\circ} \mathrm{C}$ for the primary and secondary antiserum resulted in a weak fluorescence (intensity score of 2) compared to fluorescence at $22^{\circ} \mathrm{C}$ (intensity score of 4). Inclusion of a blocking step (PBS $+2 \%$ $\mathrm{BSA}+5 \%$ goat serum) for $1 \mathrm{~h}$ prior to the primary antiserum incubation step at $22^{\circ} \mathrm{C}$ did not improve fluorescence intensity compared to the nonblocked control.

The final IFSA protocol chosen was as follows: a 500- $\mu$ l aliquot of SBR1A primary antiserum diluted 1:500 in PBSTween was placed over a sample affixed to a thin layer of petroleum jelly or doublesided tape on a standard glass microscope slide and incubated for $2 \mathrm{~h}$. The slides were then washed six times with PBSTween, and $500 \mu \mathrm{l}$ of a 1:500 dilution of Alexa Fluor 488 in PBS-Tween was added to the slides and incubated for $1 \mathrm{~h}$. Slides were washed six times as described above. All incubation steps were carried out in the dark at $22^{\circ} \mathrm{C}$.

Significantly fewer urediniospores were lost during IFSA when samples were affixed to microscope slides directly using double-sided tape or petroleum jelly than when they were captured on petroleum jelly and transferred to tape. On average, $25.0 \%$ of urediniospores were lost when transferred to tape from petroleum jellycoated slides, while only 3.7 and $5.2 \%$ of urediniospores affixed directly to tape or petroleum jelly, respectively, were lost. Nonspecific binding of the secondary antiserum to the petroleum jelly resulted in background fluorescence and weak specific fluorescence of $P$. pachyrhizi urediniospores (Fig. 2).

Polyclonal antiserum specificityIFSA. Fluorescent signals were observed over the entire surface of $P$. pachyrhizi urediniospores, with small patches of greater intensity often observed (Fig. 1D). Urediniospores of all of the $22 P$. pachyrhizi isolates tested produced high fluorescence intensity scores (scores for all isolates $=4$ ) with SBR1A antiserum in the IFSA (Table 4). Urediniospores of the $P$. meibomiae isolate PR 76 reacted positively with SBR1A antiserum, but the signal was weaker (intensity score of 3 ) than observed for urediniospores of $P$. pachyrhizi. None of the spores of nontarget species, including Ustilago and Puccinia spp., reacted positively (Table 5; Fig. 3).

Immunomonitoring of field-trapped spores. Thirty-six samples (microscope slides) were received from air samplers stationed in Georgia, Kentucky, and Ohio. Under bright field microscopy, a wide range of airborne spores, pollen, bacteria, insect, and particulate material was observed on each of the double-sided tapeaffixed and petroleum jelly-coated glass microscope slides from the field spore traps (Fig. 4). P. pachyrhizi urediniospores could not be easily distinguished from other fungal spores trapped on the slides using bright field microscopy. In some cases, urediniospores were distorted by desiccation (Fig. 4A and E). After each slide was immunolabeled, $P$. pachyrhizi urediniospores fluoresced brightly (Fig 4B, D, and F) while other fungal spores, pollen grains, bacteria, insects, and particulate material did not fluoresce. $P$. pachyrhizi urediniospores were often observed in clumps on the microscope slides. Of the 36 slides received, two were positive for $P$. pachyrhizi urediniospores from Georgia (GA12 and GA15), one from Kentucky (KY3), and six from Ohio (OH6, $\mathrm{OH} 7, \mathrm{OH} 8, \mathrm{OH} 11, \mathrm{OH} 12$, and $\mathrm{OH} 16)$ (Table 6).

Table 5. Specificity of polyclonal antiserum SBR1A against fungal spores in an immunofluorescence spore assay (IFSA)

\begin{tabular}{llc}
\hline Fungal pathogen & Host & Reactivity in IFSA $^{\mathbf{a}}$ \\
\hline Phakopsora pachyrhizi isolate TW 72-1 & Soybean (Glycine max) & 4 \\
Phakopsora meibomiae isolate PR 76 & Soybean (Glycine max) & 3 \\
Puccinia graminis f. sp. tritici & Wheat (Triticum aestivum) & 1 \\
Phragmidium sp. & Rose (Rosa spp.) & 1 \\
Ustilago tritici & Wheat (Triticum aestivum) & 1 \\
Alternaria sp. & Tomato (Solanum lycopersicum) & 1 \\
Botrytis cinerea & Tomato (Solanum lycopersicum) & 1 \\
\hline
\end{tabular}

${ }^{a}$ Fluorescence of urediniospores was rated visually using a scale of 1 to 4 where $1=$ no fluorescence, $2=$ weak fluorescence, $3=$ good fluorescence (clearly positive), and $4=$ bright fluorescence.

Table 6. Soybean rust immunofluorescence spore assay (IFSA) results for air-trapped spores on slides from Georgia, Kentucky, and Ohio, 2006

\begin{tabular}{|c|c|c|c|}
\hline Slide identification & Trapping date & Slide type & $\begin{array}{l}\text { Soybean rust } \\
\text { spores in IFSA }\end{array}$ \\
\hline GA 1 & 08.16.2006-08.23.2006 & Double-sided tape & 1 \\
\hline GA 2 & 08.02.2006-08.09.2006 & Double-sided tape & 1 \\
\hline GA 3 & $08.15 .2006-08.22 .2006$ & Double-sided tape & 1 \\
\hline GA 4 & 08.01.2006-08.08.2006 & Double-sided tape & 1 \\
\hline GA 5 & $07.31 .2006-08.07 .2006$ & Double-sided tape & 1 \\
\hline GA 6 & 08.14.2006-08.21.2006 & Double-sided tape & 1 \\
\hline GA 7 & $07.31 .2006-08.07 .2006$ & Double-sided tape & 1 \\
\hline GA 8 & $08.14 .2006-08.21 .2006$ & Double-sided tape & 1 \\
\hline GA 9 & 08.01.2006-08.08.2006 & Double-sided tape & 1 \\
\hline GA 10 & $08.10 .2006-08.17 .2006$ & Double-sided tape & 1 \\
\hline GA 11 & 08.10.2006-08.17.2006 & Double-sided tape & 1 \\
\hline GA 12 & 08.02.2006-08.09.2006 & Double-sided tape & 4 \\
\hline GA 13 & $08.16 .2006-08.23 .2006$ & Double-sided tape & 1 \\
\hline GA 14 & $08.15 .2006-08.22 .2006$ & Double-sided tape & 1 \\
\hline GA 15 & 08.01.2006-08.08.2006 & Double-sided tape & 4 \\
\hline GA 16 & 08.10.2006-08.17.2006 & Double-sided tape & 1 \\
\hline KY 1 & $07.28 .2006-08.04 .2006$ & Double-sided tape & 1 \\
\hline KY 2 & 08.04.2006-08.11.2006 & Double-sided tape & 1 \\
\hline KY 3 & $07.11 .2006-07.21 .2006$ & Double-sided tape & 4 \\
\hline KY 4 & $08.21 .2006-08.25 .2006$ & Double-sided tape & 1 \\
\hline $\mathrm{OH} 1$ & 09.01.2006-09.08.2006 & Petroleum jelly & 1 \\
\hline $\mathrm{OH} 2$ & $08.24 .2006-08.30 .2006$ & Petroleum jelly & 1 \\
\hline $\mathrm{OH} 3$ & $10.10 .2006-10.17 .2006$ & Petroleum jelly & 1 \\
\hline $\mathrm{OH} 4$ & 09.09.2006-09.16.2006 & Petroleum jelly & 1 \\
\hline $\mathrm{OH} 5$ & $09.16 .2006-09.23 .2006$ & Petroleum jelly & 1 \\
\hline $\mathrm{OH} 6$ & $07.25 .2006-07.31 .2006$ & Petroleum jelly & 3 \\
\hline $\mathrm{OH} 7$ & No date provided & Petroleum jelly & 4 \\
\hline $\mathrm{OH} 8$ & No date provided & Petroleum jelly & 4 \\
\hline $\mathrm{OH} 9$ & $09.29 .2006-10.05 .2006$ & Petroleum jelly & 1 \\
\hline OH 10 & $08.21 .2006-08.23 .2006$ & Double-sided tape & 1 \\
\hline OH 11 & No date provided & Double-sided tape & 4 \\
\hline $\mathrm{OH} 12$ & 09.05.2006-09.11.2006 & Double-sided tape & 4 \\
\hline OH 13 & 09.11.2006-09.18.2006 & Double-sided tape & 1 \\
\hline OH 14 & $09.05 .2006-09.11 .2006$ & Double-sided tape & 1 \\
\hline OH 15 & $09.25 .2006-10.03 .2006$ & Double-sided tape & 1 \\
\hline OH 16 & 10.03.2006-10.10.2006 & Double-sided tape & 4 \\
\hline
\end{tabular}

${ }^{a}$ Fluorescence of urediniospores was rated visually using a scale of 1 to 4 where $1=$ no fluorescence, $2=$ weak fluorescence, $3=$ good fluorescence (clearly positive), and $4=$ bright fluorescence. 


\section{DISCUSSION}

The ability to detect and quantify targeted airborne fungal spores rapidly and reliably will be useful in research and critical to the accuracy of disease-forecasting systems. Serological methods are potentially useful for detecting and quantifying airborne bioparticles $(8,10,13,25)$. However, although immunological methods
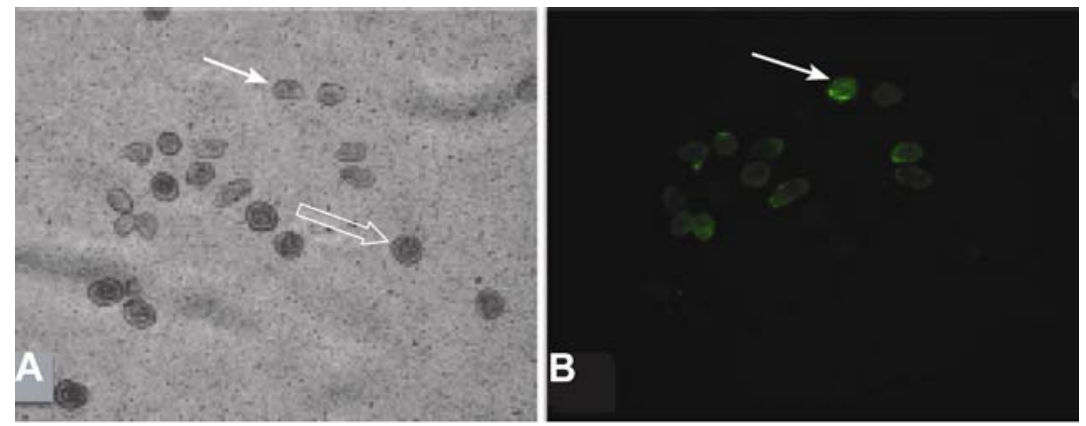

Fig. 3. Visualization of Phakopsora pachyrhizi (example shown by solid arrows) and Puccinia graminis f. sp. tritici (example shown by open arrow) with double-sided tape using A, bright field microscopy, and B, immunofluorescence spore assay (IFSA) with polyclonal antiserum SBR1A (20x objective).
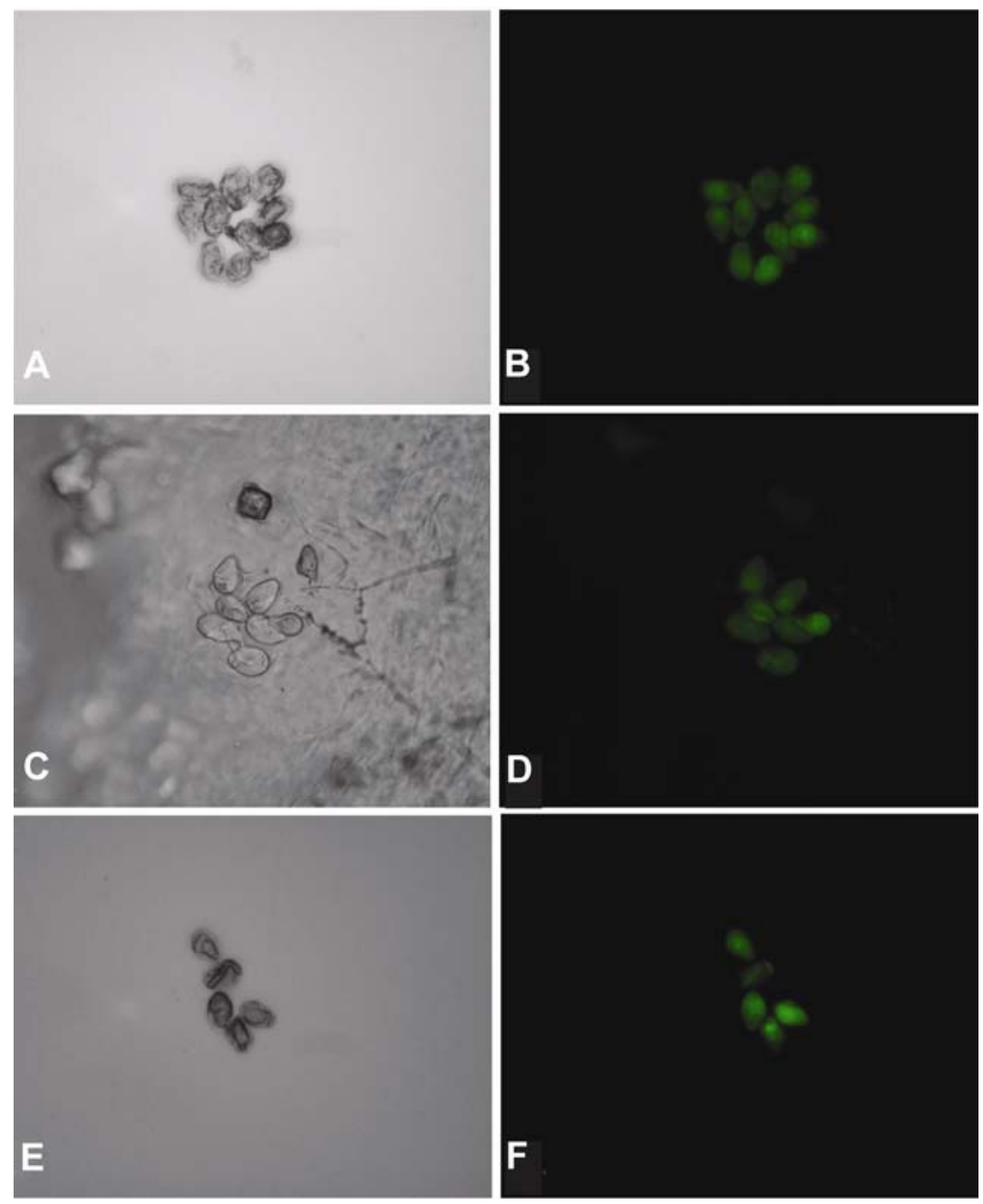

Fig. 4. Immunofluorescence spore assay (IFSA) of field-trapped soybean rust urediniospores on glass microscope slides with double-sided tape. Images in the left column were taken using bright field microscopy; images in the right column were taken of the same slides using epifluorescence microscopy. Field samples were from Ohio (A and B), Kentucky (C and D), and Georgia (E and F) (20x objective). posed in an infected onion crop and labeled directly on the tape using a Botrytisspecific monoclonal antibody (6). Kennedy et al. (20) also used immunofluorescence to detect Mycosphaerella brassicicola ascospores on Burkard spore trap tapes coated with bovine serum albumin as a support medium and blocking agent. In an alternative approach, Schmechel et al. (35) developed a prototype rotating-arm sampler, designed for use with ELISA, to detect and enumerate airborne spores. The trap was tested in wind tunnel experiments with Alternaria brassicae conidia utilizing a monoclonal antibody against germinating conidia of this pathogen $(36,37)$. More recently, a new particle-trapping device, the microtiter immunospore trap, was developed by the Burkard Manufacturing Co., Rickmansworth, UK (19). The device uses a suction system to collect airborne particles directly into the wells of a microtiter plate. Kennedy et al. (19) demonstrated the utility of this device for detecting airborne spores of $M$. brassicicola and $B$. cinerea by ELISA. We found in this study that $P$. pachyrhizi urediniospores captured in a passive air sampler could be quickly and easily identified. The advantage of immunofluorescence over ELISA is that immunolabeled spores can be directly visualized and counted. Further, a passive air sampler such as the one used in this study is simple, inexpensive, and fully adapted to urediniospore capture on slides placed inside.

The polyclonal antisera developed to different fungal immunogen preparations displayed a range of specificity. The most specific antisera were developed against pulverized, nongerminated urediniospores of $P$. pachyrhizi. This approach may be particularly appropriate for an immunofluorescence assay because it appears to enrich for antibodies to urediniospore surface epitopes. Meyer and Dewey (27) demonstrated that genus-specific monoclonal antibodies capable of binding surface epitopes of Botrytis cinerea conidia were most reactive in ELISA and immunofluorescence assays.

We found that the efficiency of visualization of immunofluorescent urediniospores on microscope slides affixed with double-sided tape was substantially superior to that of slides coated with petroleum jelly. In experiments in which the primary antiserum was omitted, the secondary antiserum conjugated with Alexa Fluor 488 appeared to bind nonspecifically with urediniospores on petroleum jellycoated slides (data not shown). It is likely that the petroleum jelly interfered with effective washing of the secondary antibody. While retention of urediniospores on tape and petroleum jelly throughout IFSA was similar (approximately 95 to $97 \%$ retention), transferring urediniospores from petroleum jelly to tape resulted in significant losses of spores (approximately 
$75 \%$ retention). The air samplers currently being used for $P$. pachyrhizi urediniospores sampling were originally designed to use petroleum jelly-coated slides, but our results clearly demonstrate that doublesided tape is the superior urediniospore capture material where IFSA will be used. Preliminary results from field tests with double-sided tape or petroleum jellycoated glass microscope slides collected from field tests in 2006 demonstrate that the IFSA combined with spore trapping can be an effective tool for monitoring $P$. pachyrhizi urediniospores movement during the soybean growing season.

In future studies, we will investigate the use of monoclonal antibodies specific to the urediniospores of $P$. pachyrhizi. The monoclonal antibodies will be assessed in the test format described above, and the potential for a continuous detection assay will also be investigated. It is clear that immunological techniques have the potential to play a significant role in the detection and monitoring of airborne plant pathogens such as the soybean rust pathogen, $P$. pachyrhizi.

\section{ACKNOWLEDGMENTS}

We thank Tea Meulia for assistance with fluorescent microscopy techniques, and Ohio Agricultural Research and Development Center Molecular and Cellular Imaging Center for providing microscopy and image analysis facilities. This project was sponsored through soybean check-off dollars from Iowa Soybean Association and United Soybean Board. Salaries and research support provided by state and federal funds appropriated to the Ohio Agricultural Research and Development Center, The Ohio State University. Mention of trade names or commercial products in this publication is solely for the purpose of providing specific information and does not imply recommendation or endorsement by the U.S. Department of Agriculture or The Ohio State University.

\section{LITERATURE CITED}

1. Akinsanmi, O. A., Ladipo, J. L., and Oyekan, P. O. 2001. First report of soybean rust (Phakopsora pachyrhizi) in Nigeria. Plant Dis. 85:97.

2. Asian Vegetable Research and Development Center. 1987. Bibliography of soybean rust, 1985-1986. AVRDC Publication No. 87-277. Shanhua, Tainan, Taiwan, ROC.

3. Asian Vegetable Research and Development Center. 1992. Annotated bibliography of soybean rust (Phakopsora pachyrhizi Sydow). AVRDC Publication No. 92:372. Shanhua, Tainan, Taiwan, ROC.

4. Baysal, F., Dorrance, A., Ivey, M. L. L., Luster, D., Frederick, R., Czarnecki, J., Boehm, M., and Miller, S. A. 2007. An immunofluorescence assay to detect soybean rust urediniospores. (Abstr.) Phytopathology 97:S9.

5. Beck, J., Ligon, J. J., Ettienne, L., and Binder, A. 1996. Detection of crop fungal pathogens by polymerase chain reaction technology. Pages 111-118 in: Diagnostics in Crop Production. BCPC Symposium No. 65. G. Marshall, ed. British Crop Protection Council, Farnham, UK.

6. Bossi, R., and Dewey, F. M. 1992. Development of a monoclonal antibody-based immunodetection assay for Botrytis cinerea. Plant Pathol. 41:472-482.

7. Bradford, M. M. 1976. A rapid and sensitive method for the estimation of microgram quantities of protein utilizing the principle of pro- tein-dye binding. Anal. Biochem. 72:248-254.

8. Burge, H. A., and Solomon, W. R. 1987. Sampling and analysis of biological aerosols. Atmos. Environ. 21:451-456.

9. Cherry, E., and Peet, C. 1966. An efficient device for the rapid collection of fungal spores from infected plants. Phytopathology 56:11021103.

10. DeCosemo, G. A. L., Stewart, I. W., Griffiths, W. D., and Deans, J. S. 1992. The assessment of airborne microorganisms. J. Aerosol Sci. 23:S683-686

11. Dewey, F. M. 1996. Production and use of monoclonal antibodies for the detection of fungi. Pages 85-91 in: Diagnostics in Crop Production. BCPC Symposium Proceedings No. 65. G. Marshall, ed. British Crop Protection Council, Farnham, UK.

12. Dorrance, A. E., Draper, M. A., and Hershman, D. E., eds. 2005. Using Foliar Fungicides to Manage Soybean Rust. NC-504 Land Grant Universities Cooperating. Bull. SR-2005.

13. Flannigan, B. 1997. Air sampling for fungi in indoor environments. J. Aerosol Sci. 28:381392.

14. Frederick, R. D., Snyder, C. L., Peterson, G. L., and Bonde, M. R. 2002. Polymerase chain reaction assays for the detection and discrimination of the soybean rust pathogens Phakopsora pachyrhizi and P. meibomiae. Phytopathology 92:217-227.

15. Hirst, J. M. 1953. Changes in Atmospheric Spore Content: Diurnal Periodicity and the Effects of Weather. Trans. Br. Mycol. Soc. 36:375-392.

16. Isard, S. A., Russo, J. M., and DeWolf, E. D. 2006. The establishment of a national Pest Information Platform for Extension and Education. Plant Health Progress Online: doi:10. 1094/PHP-2006-0915-01-RV.

17. Jamaux, I., and Spire, D. 1994. Development of a polyclonal antibody-based immunoassay for the early detection of Sclerotinia sclerotiorum in rapeseed petals. Plant Pathol. 43:847-862.

18. Jost, P., Harris, G., Harrison, K., Kemerait, R., McPherson, R., Prostko, E., Roberts, P., Raymer, P., Shumaker, G., and Sumner, P. 2005. Georgia Soybean Production Guide. University of Georgia Cooperative Extension Bull. CSS05-02.

19. Kennedy, R., Wakeham, A. J., Byrne, K. G., Meyer, U. M., and Dewey, F. M. 2000. A new method to monitor airborne inoculum of the fungal plant pathogens Mycosphaerella brassicicola and Botrytis cinerea. Appl. Environ. Microbiol. 66:2996-3000.

20. Kennedy, R., Wakeham, A. J., and Cullington, J. E. 1999. Production and immunodetection of ascospores of Mycosphaerella brassicicola: Ringspot of vegetable crucifers. Plant Pathol. 48:297-307.

21. Levy, C. 2003. Measures to control soybean rust in Southern Africa and an initial investigation of the meteorological factors that favor its development. (Abstr.) Phytopathology 93:S103.

22. Lewis Ivey, M. L., Nava Diaz, C., and Miller, S. A. 2004. Identification and management of Colletotrichum acutatum on immature bell peppers. Plant Dis. 88:1198-1204.

23. Livingston, M., Johnson, R., Daberkow, S., Roberts, M., Ash, M., and Breneman, V. 2004. Economic and policy implications of windborne entry of Asian soybean rust into the United States. USDA Economic Research Service OCS-04D-42. http://www.ers.usda.gov.

24. Markwell, M. A., Haas, S. M., Tolbert, N. E., and Bieber, L. L. 1981. Protein determination in membrane and lipoprotein samples: Manual and automated procedures. Methods Enzymol. 72:296-303.

25. McCartney, H. A., Fitt, B. D. L., and Schmechel, D. 1997. Sampling bioaerosols in plant pathology. J. Aerosol Sci. 28:349-364.
26. Melching, J. S., Bromfield, K. R., and Kingslover, C. H. 1983. The plant pathogen containment facility at Frederick, Maryland. Plant Dis. 67:717-722.

27. Meyer, U., and Dewey, F. M. 2000. Efficacy of different immunogens for raising monoclonal antibodies to Botrytis cinerea. Mycol Res 104:979-987.

28. Miles, M. R., Hartman, G. L., and Frederick, R. D. 2003. Soybean rust: Is the U.S. crop at risk? American Phytopathological Society. Online feature. http://www.apsnet.org/online/ feature/rust.

29. Miles, M. R., Hartman, G. L., Levy, C., and Morel, W. 2003. Current status of soybean rust control by fungicides. Pestic. Outlook 14:197200.

30. Miles, M. R., Levy, C., Morel, W., Mueller, T., Steinlage, T., van Rij, N., Frederick, R. D., and Hartman, G. L. 2007. International fungicide efficacy trials for the management of soybean rust. Plant Dis. 91:1450-1458.

31. Morel, W. P. 2001. Roya de la soja. Ministerio de Agricultura y Ganaderia, Subsecretaria de Agricultura, Direccion de Investigacion Agricola, Centro Regional de Investigacion Agricola-CRIA, Capitan Miranda, Itapua, Paraguay. Comunicado Tecnico-Report Official, Serie Fitopathologia, 1, Junio de 2001.

32. Mullins, J., and Emberlin, J. 1997. Sampling pollens. J. Aerosol Sci. 28:365-370.

33. Pretorius, Z. A., Kloppers, F. J., and Frederick, R. D. 2001. First report of soybean rust in South Africa. Plant Dis. 85:1288.

34. Rossi, R. L. 2003. First report of Phakopsora pachyrhizi, the causal organism of soybean rust in the province of Misiones, Argentina. Plant Dis. 87:102

35. Schmechel, D., McCartney, H. A., and Halsey, K. 1994. The development of immunological techniques for the detection and evaluation of fungal disease inoculum in oilseed rape crops. Pages 247-253 in: Modern Detection Methods for Plant Pathogenic Fungi: Identification, Detection and Quantification. A. Schots, F. M. Dewey, and R. Oliver, eds. CAB International, Wallingford, UK.

36. Schmechel, D., McCartney, H. A., and Magan, N. 1996. A novel approach for immunomonitoring air-borne fungal pathogens. Pages 93-98 in: Diagnostics in Crop Production. BCPC Symposium Proceedings No. 65. G. Marshall, ed. British Crop Protection Council, Farnham, UK.

37. Schmechel, D., McCartney, H. A., and Magan, N. 1997. The production and characterization of monoclonal antibodies against Alternaria brassicae (Berk.) Sacc., the cause of dark leaf and pod spot in oilseed rape. Food Agric. Immunol. 9:219-232.

38. Schneider, R. W., Hollier, C. A., Whitam, H. K., Palm, M. E., McKemy, J. M., Hernández, J. R., Levy, L., and DeVries-Paterson, R. 2005. First report of soybean rust caused by Phakopsora pachyrhizi in the continental United States. Plant Dis. 89:774.

39. U.S. Department of Agriculture. 2007. Pest information platform for extension and education. Available April 1, 2007, from http://www.sbrusa.net/cgi-bin/sbr/public.cgi.

40. Werres, S., and Steffens, C. 1994. Immunological techniques used with fungal plant pathogens: Aspect of antigens, antibodies and assays for diagnosis. Ann. Appl. Biol. 125:615-643.

41. Yang, X. B., and Pan, Z. 2007. Soybean rust update and outlook, June 2007. Integrated Crop Management, the IC-498(14).

42. Yorinori, J. T., Paiva, W. M., Frederick, R. D. Costamilan, L. M., Bertagnolli, P. F., Hartman, G. E., Godoy, C. V., and Nunes, J., Jr. 2005. Epidemics of soybean rust (Phakopsora pachyrhizi) in Brazil and Paraguay from 2001 to 2003. Plant Dis. 89:675-677. 